\title{
Ankyloglossia (Tongue-Tie) - To Snip or Not to Snip: An Integrative Literature Review
}

\author{
Ryndell Levkovich, Mary Sidebotham, Karolyn Vaughan, and \\ Elaine Dietsch
}

PURPOSE: Ankyloglossia (commonly referred to as tongue-tie), is increasingly being reported as a significant contributory factor to difficulties experienced in establishing the mother-infant breastfeeding relationship. Frenotomy as a management option is contributing to international interest and interdisciplinary controversy. The aim of this article was to identify and examine the evidence in relation to frenotomy to inform practice for newborns diagnosed with symptomatic ankyloglossia.

DESIGN: An integrated literature review, informed by Whittemore and Knafl (2005) was used to identify and evaluate contemporary evidence.

MAJOR FINDINGS: There is a marked difference in opinion between health disciplines regarding frenotomy as a treatment option for ankyloglossia. There is agreement that support from a trained professional such as a lactation consultant prior to undergoing any invasive procedures to treat ankyloglossia is essential. Controversy persists however as to whether the condition will resolve spontaneously without treatment.

CONCLUSION: Although frenotomy does seem to resolve breastfeeding difficulties, little is known regarding long-term consequences for the baby and optimal timing for the procedure. This review indicates a need for education of professionals and standardization of assessment processes along with ongoing research to identify efficacy and optimal timing of frenotomy when used.

KEYWORDS: frenotomy; breastfeeding challenges; infant-mother dyad; tongue-tie division

\section{INTRODUCTION}

Tongue-tie or ankyloglossia, as it will be referred to in this article, is a congenital condition that is characterized by an abnormally short, thickened, or tightened lingual frenulum (Braccio, Chadderton, Sherridan, \& Upadhyaya, 2016; Burrows \& Lanlehin, 2015; Edmunds, Fulbrook, \& Miles, 2013; Todd, 2014). Ankyloglossia often restricts the normal mobility of the tongue and the primary symptom is difficulty in establishing breastfeeding. Mothers of infants with ankyloglossia report an extensive range of breastfeeding problems including but not limited to:

- Difficulty with latching or poor latch (Berry, Griffiths, \& Westcott, 2012; Braccio et al., 2016; Brookes \&
Bowley, 2014; Dollberg, Marom, \& Botzer, 2014; Martinelli, Marchesan, Gusmão, Honório, \& BerretinFelix, 2015; O'Callahan, Macary, \& Clemente, 2013)

- Nipple pain (Berry et al., 2012; Braccio et al., 2016; Brookes \& Bowley, 2014; Dollberg et al., 2014; Martinelli et al., 2015; O'Callahan et al., 2013)

- Nipple trauma-including cracked, ulcerated, bleeding, and distorted nipples (Brookes \& Bowley, 2014; Francis, Krishnaswami, \& McPheeters, 2015; Mettias, O’Brien, Abo Khatwa, Nasrallah, \& Doddi, 2013)

- Inefficient feeding-frequent feeds, unsatisfied infant (Berry et al., 2012; Braccio et al., 2016; Brookes \& Bowley, 2014)

- Decreasing milk supply (Berry et al., 2012; Edmunds et al., 2013; Mettias et al., 2013) 
- Inadequate milk transfer (Edmunds, Miles, \& Fulbrook, 2011; Martinelli et al., 2015)

- Singular or recurring mastitis (Brookes \& Bowley, 2014)

- Poor infant weight gain (Edmunds et al., 2013;

Francis et al., 2015; O'Callahan et al., 2013)

- Breast refusal (Francis et al., 2015; Mettias et al., 2013).

The reported incidence of ankyloglossia ranges between $0.1 \%$ and $10.7 \%$. This wide range can be explained by the current lack of conformity within the literature for the identification, grading, assessment and diagnosis of the condition (Sethi, Smith, Kortequee, Ward, \& Clarke, 2013). The more recent literature suggests that diagnosis should be based on a comprehensive clinical examination with assessment of the appearance and mobility of the tongue, together with the attachment, insertion, and shortness of the lingual frenulum. The use of a validated instrument such as the Hazelbaker Assessment Tool (Amir, James, \& Donath, 2006), is recommended, to support the examination. To increase accuracy and provide appropriate/management advice, clinical assessment and the use of assessment tools should be performed by a practitioner who has achieved accreditation through education and training (Tsaousoglou, Topouzelis, Vouros, \& Sculean, 2016).

Despite the current lack of standardized assessment processes and supporting evidence of efficacy, frenotomy is an intervention that is often used to treat ankyloglossia with associated breastfeeding difficulties. The frenotomy procedure involves the release of the tongue from the floor of the mouth by "snipping" the ankyloglossia with a sharp pair of blunt ended scissors at the base of the tongue or with laser (Kotlow, 2011; Todd, 2014).

The purpose of this literature review is to identify and examine the evidence in relation to the use of frenotomy for the treatment symptomatic ankyloglossia. This will enable the reader to develop a comprehensive understanding of this complex health issue and make informed decisions around the practice of frenotomy for newborns diagnosed with the condition.

\section{METHODOLOGY}

An integrative literature review, based on the methods proposed by Whittemore and Knafl (2005) was used to gather contemporary data from qualitative, quantitative, and theoretical research, as well as the grey literature. A five-stage process for conducting the integrative literature review was followed and included (1) problem identification, (2) literature search, (3) data evaluation, (4) data analysis, and (5) presentation of results (Whittemore \& Knafl, 2005).

\section{Problem Identification}

Optimal management of the infant with symptomatic ankyloglossia is not clearly established in the literature, and this has led to significant variation in practices depending on the clinician's professional discipline and background. Therefore, the purpose of this integrative literature review was to examine some of the controversies surrounding the use of frenotomy and to gather evidence that could be used to better inform clinicians who may be supporting parents who have an infant with a symptomatic ankyloglossia.

\section{Literature Search}

A search of the literature was conducted in six health specific databases: Cumulative Index to Nursing and Allied Health (CINAHL), Cochrane Library, MEDLINE, PubMed, ScienceDirect, and ClinicalKey. The keywords and Boolean operators used across all databases were tongue tie OR ankyloglossia AND frenotomy AND treatment. The following inclusion criteria were then applied: articles published since 2010, available as full text in the English language, and peer reviewed.

Topic refiners of tongue, infant, oral, pediatric, breast and milk were added to the search within ScienceDirect. Once duplicates were removed from all the searches, the final number of articles moving through to the evaluation stage was 235 . Table $1 \mathrm{dem}-$ onstrates the audit trail related to the number of articles included for evaluation, prior to the in-depth review.

TABLE 1 Audit Trail of Articles Reviewed From Each Database

$\begin{array}{lcc}\text { NUMBER OF } & \begin{array}{c}\text { FINAL NUMBERS OF } \\ \text { ARTICLES } \\ \text { RETURNED }\end{array} & \begin{array}{c}\text { ARTICLES INCLUDED } \\ \text { FOR REVIEW }\end{array} \\ \text { DATABASE } & 99 & 11 \\ \text { CINAHL } & 1 & 1 \\ \text { Cochrane Library } & 30 & 23 \\ \text { MEDLINE } & 452 & 63 \\ \text { PubMed } & 1,945 & 39 \\ \text { ScienceDirect } & 108 & 99 \\ \text { ClinicalKey } & & \end{array}$

Note. CINAHL $=$ Cumulative Index to Nursing and Allied Health. 


\section{Data Evaluation}

The data evaluation stage of this review was completed in two parts because of the large number of studies returned from the database searches. Inclusion and exclusion criteria were developed, and each article was critiqued against this list of criteria before being put forward for the in-depth analysis. Building on the criteria for the literature search, articles were excluded in the data evaluation process if they were editorials, related to children and adults (rather than newborn, breastfeeding infants up to 3 months of age) and if the ankyloglossia was not the primary diagnosis impacting on breastfeeding. Once this initial critique was complete, 36 studies remained to be examined in the second part of the evaluation process.

The 36 articles remaining were then all evaluated to ensure the data were relevant to the identified problemfrenotomy as a management option for symptomatic ankyloglossia. Further critique and exclusions were made based on the articles' relevance: inadequate sample sizing (including singular case studies and research with less than 10 subjects/participants); if there was no evidence of ethical consideration such as Institutional Ethics Committee approval; if the focus was on preferred types of treatment (laser or surgical); of if the research focused on children, teenagers, or adults with ankyloglossia. This critique resulted in 19 studies progressing through to the analysis phase of this literature review. The reference lists for each of the 19 articles were searched to identify any other studies that could potentially meet the inclusion criteria but no additional papers were sourced. Finally, a search and examination of current citations of the 19 selected papers was made within the Google Scholar database, but no new papers were identified.

\section{Data Analysis}

The 19 articles included for analysis were grouped into two categories- "original research" and "reviews" (Appendices A and B). All articles were individually reviewed and then a constant comparison method was used to enable the generation of findings into themes and subthemes.

\section{Presentation of Results}

Three main findings/themes were identified during the analysis process and have been identified as (a) not to snip, (b) to snip, and (c) difference in expert opinions. Subthemes were identified and explored within these main themes (Table 2).

\section{Not to Snip}

Within the first theme, not to snip, three subthemes were identified: the basis for not snipping; the trauma caused to the infant (and distress to the parent); and finally, the availability of effective diagnosis and noninvasive treatment options which are the themes outlined in the following text.

Sethi et al. (2013) collected data from 52 mothers of infants who had undergone frenotomy via a telephone call using a nonvalidated questionnaire developed for the study. The results demonstrated that most women $(77 \%)$ experienced improvements in breastfeeding postfrenotomy, but a significant portion of women (23\%) experienced no improvement in breastfeeding following the procedure. The authors therefore argued that frenotomy should not be the initial response to ankyloglossia and that a more holistic, noninvasive

TABLE 2 Identification of Themes and Subthemes

\begin{tabular}{ll}
\hline THEME & SUBTHEMES \\
\hline Not to snip & Basis for not performing a frenotomy (Riskin et al., 2014; Sethi et al., 2013) \\
& Trauma and distress (Burrows \& Lanlehin, 2015) \\
& Availability of effective diagnosis and noninvasive intervention options (Sethi et al., 2013) \\
& Benefits of frenotomy (Berry et al., 2012; Braccio et al., 2016; Brookes \& Bowley, 2014; \\
To snip & Buryk, Bloom, \& Shope, 2011; Dollberg et al., 2014; Martinelli et al., 2015; \\
& Mettias et al., 2013; O’Callahan et al., 2013) \\
& Skills and training for effective diagnosis and treatment (Burrows \& Lanlehin, 2015; \\
& Edmunds et al., 2013; Sethi et al., 2013) \\
& Timing of intervention (Berry et al., 2012; Emond et al., 2014; Power \& Murphy, 2015; \\
& Riskin et al., 2014; Steehler, Steehler, \& Harley, 2012; Todd, 2014; Todd \& Hogan, 2015) \\
& Variation of opinions based on profession (Edmunds et al., 2011; Francis et al., 2015; \\
Mettias et al., 2013; Power \& Murphy, 2015; Sethi et al., 2013)
\end{tabular}


approach should be used as the primary treatment. Sethi et al. (2013) suggest that support and health information sharing from lactation consultants (International Board Certified Lactation Consultants ${ }^{\circledast}$ [IBCLCs] and other health professionals who support breastfeeding women and their infants) should be used to assist women to gain confidence with breastfeeding and attachment as ankyloglossia was not the only or most significant factor inhibiting breastfeeding for many participants in their study. Breastfeeding support and health information sharing often led to a spontaneous improvement in breastfeeding problems when ankyloglossia was present without the need for an invasive procedure. Conclusions from the Riskin et al. (2014) study were congruent with those of Sethi et al. in that frenotomy should not be a primary source of treatment for ankyloglossia. The Riskin et al. retrospective, single center observational study used a structured survey instrument with 183 mothers whose infants had been diagnosed with ankyloglossia and a control group of 314 mothers whose infants did not have ankyloglossia. They found that many mother-infant dyads within the frenotomy group continued to experience breastfeeding problems and $40 \%$ continued to feel dissatisfied with breastfeeding following frenotomy. Both studies (Riskin et al., 2014; Sethi et al., 2013) recommended that lactation consultants should first be sought to provide a more holistic assessment and treatment through support and health information sharing prior to moving to an invasive intervention. Neither study identifies when talking about lactation consultants if they are referring to IBCLC ${ }^{\circledast}$ with ankyloglossia specialization or of other health professionals who support breastfeeding women and their infants. Women who had infants with ankyloglossia and did not seek frenotomy reported higher rates of satisfaction with lactation consultants (77\%) compared with $59 \%$ of women whose infants had undergone frenotomy (Riskin et al., 2014). The authors argue that compared with frenotomy, noninvasive support options of mother-infant dyads when the infant has been diagnosed with ankyloglossia resulted in fewer unnecessary invasive procedures and enhanced satisfaction of mothers with their breastfeeding relationship (Riskin et al., 2014). In this study by Riskin et al., the tongueties were diagnosed by health care professionals during routine assessments and confirmed by a neonatologist; however, a specific tool was not used and the subjectivity of the diagnosis is a limitation of the outcomes data.

Parents often experience distress associated with their infants experiencing an invasive procedure including frenotomy (Burrows \& Lanlehin, 2015), despite the often repeated reassurance from treating clinicians that the procedure is pain and harm free. Most literature reports that the process of frenotomy is painless and carries minimal risks with it, minimizing the need for anesthetic and increasing the availability of the procedure. However, Burrows and Lanlehin (2015) argued that the same was once believed of male infant circumcision and recommended that more research is needed to ascertain pain and longer term psychological effects on the infant who has undergone frenotomy because frenotomy could be a cause of significant disruption to the infant's normal early psychological development. Burrows and Lanlehin considered the Freudian psychosexual stages, where the oral stage is the primary phase where infants explore and gain pleasure through the mouth and ask the question if performing a frenotomy may cause long-term stress.

Sethi et al. (2013) argue that health professionals may lack the skills to appropriately identify and treat ankyloglossia in infants, which could result in infants being put through an unnecessary procedure if the diagnosis or management is incorrect. An essential point made by Sethi et al. (2013) is that not all infants who have ankyloglossia will have breastfeeding difficulties and that some who do have the condition will have initial feeding difficulties that may self-resolve with breastfeeding support and health information sharing. The possibility that ankyloglossia may self-resolve however raises controversy among breastfeeding support professionals and researchers and is an ongoing topic of discussion and debate.

\section{To Snip}

The second theme relates to recommendations that infants affected by ankyloglossia undergo frenotomy. Three subthemes relate to the recommendation and they are the benefits of frenotomy, skills and training for effective diagnosis and treatment, and timing of the intervention.

The mother-infant breastfeeding relationship commences with the first feed, and difficulties experienced with establishing breastfeeding have the potential to negatively impact this relationship if not identified and managed within the first few days. The stress and anxiety that mothers feel when challenged by breastfeeding difficulties often impact negatively on the mother-infant breastfeeding relationship (Edmunds et al., 2013; Todd, 2014). In a study conducted by Edmunds et al. (2013), women whose infants were diagnosed with ankyloglossia had started to question themselves and their ability 
to mother their infant. Some of the women in the study however reported feeling relief at the diagnosis as they felt they were able to trust themselves and their mothering abilities and improve their relationship with their infant once a reason for the difficulty had been found. In studies conducted by Martinelli et al. (2015) and Todd (2014), frenotomy and to a lesser extent, a placebo procedure, helped many women to establish the emotional connection between herself and her infant and subsequently enhanced the breastfeeding relationship.

In addition to improvements made in the motherinfant relationship, Sethi et al. (2013) and Dollberg et al. (2014) both reported resolution of breastfeeding and latching difficulties postfrenotomy ( $77 \%$ and $75 \%$, respectively). Braccio et al. (2016) also found a statistically significant decrease in breastfeeding problems particularly latch related issues postfrenotomy. Buryk et al. (2011) conducted a randomized single blinded, controlled trial where infants with breastfeeding difficulties and significant ankyloglossia were randomly assigned to either undergo a frenotomy procedure (30 infants) or placebo (28 infants). Infants in the placebo group stayed in the treatment room for the same length of time as the infants undergoing frenotomy but had no procedure performed. Mothers from both groups were blinded to the procedure and instructed not to look in the infant's mouth. Although both groups reported decreases in maternal nipple pain scores and improved breastfeeding postprocedure, the improvements in the frenotomy group were greater and statistically significant.

Congruent with Buryk et al. (2011) and Braccio et al. (2016), Brookes and Bowley (2014) reported that frenotomy in infants with breastfeeding difficulties associated with ankyloglossia resulted in objective improvements in breastfeeding characteristics, including infant weight gain, milk production, and reduction in maternal discomfort/pain. Reduction of nipple pain (one of the major causes of weaning) was a common finding from multiple studies (Braccio et al., 2016; Brookes \& Bowley, 2014; Mettias et al., 2013; O’Callahan et al., 2013), as was improved latching (Braccio et al., 2016; Mettias et al., 2013; O'Callhan et al., 2013). Mettias et al. (2013) also found that $77 \%$ of parents had only positive feedback regarding the procedure, whereas similarly, Braccio et al. found that $75.9 \%$ of parents provided feedback of " $5 / 5$ " satisfaction with the service.

Accurate diagnosis of ankyloglossia is essential before any management options can be considered. This review identified the need for clinicians working with breastfeeding mothers and their infants, including midwives and lactation consultants to be adequately trained to assess, identify, and classify ankyloglossia. Clinicians supporting breastfeeding women and infants need to provide support, information, and reassurance to women whose infants have symptomatic ankyloglossia. Deficits in knowledge among supporting clinicians can negatively impact both the women and their infants (Burrows \& Lanlehin, 2015; Sethi et al., 2013). The understanding that not all infants with ankyloglossia will have significant breastfeeding problems will help in the accurate determining of those infants where invasive intervention is required. A uniform approach, using a validated instrument (the Hazelbaker Assessment Tool) to screen for ankyloglossia and determine optimal management options should be a competency that all health care workers working with women and infants have (Burrows \& Lanlehin, 2015; Edmunds et al., 2011; Sethi et al., 2013).

The recommended timing of frenotomy for symptomatic ankyloglossia varies greatly. "Too early" frenotomy may mean that the breastfeeding challenges may have resolved spontaneously and the infant has undergone an unnecessary and invasive procedure. "Too late" frenotomy may result in exacerbation of breastfeeding difficulties with potential cessation of breastfeeding (Berry et al., 2012; Power \& Murphy, 2015). To minimize the potential for resolution of breastfeeding problems most, but not all, studies indicated that the earlier the procedure was performed the better for both breastfeeding outcomes and decreased trauma (Berry et al., 2012; Riskin et al., 2014; Todd \& Hogan, 2015). Frenotomy is routinely performed on newborns under the age of 3 months without anesthetic because it is not perceived as being traumatic or painful at this age (Mettias et al., 2013; Power \& Murphy, 2015). Power and Murphy (2015) found that the timing of frenotomy in most studies ranges on average from 6 to 21 days of age. They found that if nipple pain and latching difficulties are still evident at 3 weeks of age then there is a $10 \%-26 \%$ chance of early cessation of breastfeeding. Todd (2014) and Todd and Hogan (2015), compared frenotomy performed prior to 7 days with after 7 days of life. Their data showed that delaying the frenotomy until after 7 days resulted in a greater breastfeeding cessation rate. When frenotomy was delayed, there was a significant increase in the number of women bottle feeding either with expressed breast milk or formula, resulting in reduced breast milk supply, mastitis, engorgement, early complete cessation of breastfeeding, and difficulty with reestablishing the infant at the breast after frenotomy (Todd, 2014; Todd \& Hogan, 2015). Riskin et al. (2014) and Berry et al. (2012) also recommend 
early frenotomy (in the first 8 days of life) and reported that later frenotomy resulted in lower satisfaction rate with the procedure in helping to solve breastfeeding problems. Mothers who recounted full resolution of their breastfeeding problems had infants with a mean age of 8 days younger than those who saw only minimal improvements (Berry et al., 2012). However, Edmond et al. (2014) reported that 5 days was the length of time which most women were prepared to continue with painful and difficult breastfeeding before requesting a frenotomy or moving to other means of feeding. The study by Steehler et al. (2012) had an older median age of 18 days of life when frenotomy was performed compared to the studies by Todd and Hogan (2015) and Berry et al. (2012). However, they too found higher satisfaction rates with the procedure and the associated outcomes in mothers when the procedure was performed within the first week of the infant's life.

\section{Difference of Opinion}

The final theme identified in the literature was difference of opinion regarding ankyloglossia and the need for frenotomy based on the professional grouping of the health care professional. The role of the health care professional (general practitioners, paediatricians, midwives, lactation consultants, and child and family health nurses) in supporting women with breastfeeding problems has led to a renewed interest in the diagnosis and treatment of ankyloglossia in newborns (Power \& Murphy, 2015; Sethi et al., 2013). Power and Murphy (2014) found that pediatricians are least likely to recommend frenotomy and $90 \%$ of pediatricians believe that ankyloglossia rarely causes problems. Similar to Power and Murphy, Rowan-Legg (2015) identified that pediatricians often consider that the improvement in breastfeeding after frenotomy is caused by placebo effect and that if given support and time to become more proficient with breastfeeding, most women would see spontaneous improvements without invasive intervention. Francis et al. (2015) and Mettias et al. (2013) also found that only $10 \%$ of pediatricians and $30 \%$ of otolaryngologists believe that breastfeeding is impacted by ankyloglossia in comparison to $69 \%$ of lactation consultants who believe that it is a frequent source of breastfeeding challenges. Edmunds et al. (2011) highlight that the omission of guidelines or position statements by the American College of Pediatricians and the Royal Australasian College of Physicians, Paediatrics \& Child Health Division, would suggest that there is a lack of consensus around the management and treatment for symptomatic ankyloglossia. Some pediatricians are concerned that the liberal use of frenotomy for ankyloglossia without significant clinical need may lead to a rise in infants being subjected to an unnecessary invasive procedure (Power \& Murphy, 2015).

Lactation consultants and midwives work with women to overcome breastfeeding problems and are often the first to identify a problem such as ankyloglossia. If support and noninvasive interventions are not able to assist in improving the problem, then referral for further assessment and possible frenotomy is usually recommended. Edmunds et al. (2011) suggest the need to be referred by a general practitioner for the procedure or further assessment and referral, but this may be declined because the general practitioner may not agree that ankyloglossia is causing the breastfeeding problems (Edmunds et al., 2011).

This lack of consensus among health care professionals regarding the diagnosis and treatment of ankyloglossia means that many parents are being given inconsistent and often conflicting advice. This confirms the need for more research and targeted education to ensure that health professionals supporting breastfeeding women provide evidence-based information to parents to facilitate informed decision making (Edmunds et al., 2011; Power \& Murphy, 2015).

One aspect of ankyloglossia management that most health care professionals agree is that if the ankyloglossia is not negatively affecting breastfeeding then there is no need for invasive intervention (Edmunds et al., 2011; Francis et al., 2015).

\section{RECOMMENDATIONS}

It is evident from this literature review that there is a need for further research regarding ankyloglossia and its impacts on both mother and infant. The findings of current and future research should inform comprehensive education packages for health professionals supporting breastfeeding women to improve assessment and diagnosis and to provide evidence informed information to parents to enable them to make decisions regarding possible treatment/management options. The review also identified the need for a standardized approach to be adopted around the diagnosis of ankyloglossia. Adopting a standardized process using a reliable tool could increase accuracy in diagnosis and reduce the variance observed in the numbers of infants diagnosed with the condition. There are several tools currently available to assist in the assessment and diagnosis of ankyloglossia 
including the Bristol Tongue Assessment Tool (Ingram et al., 2015), and the Hazelbaker Assessment Tool. There is long-standing consensus that the Hazelbaker Assessment Tool is a reliable tool (Amir et al., 2006), and wider use of this tool within the assessment process could provide practitioners with a standardized approach to assess and identify ankyloglossia. Using a standardized approach to diagnosis also has the potential to minimize unnecessary invasive treatments and reduce the difference of opinion among health professionals identified within this review regarding diagnosis and the need for treatment. It is important to note though that before any standardized assessment process is introduced, all health professionals should receive appropriate training and credentialing in the use of any associated assessment tools and should have access to ongoing clinical support (Ingram et al., 2015).

With the current public health focus on increasing rates of exclusive breastfeeding, it is important to ensure breastfeeding guidelines and practices promote the establishment of a successful breastfeeding relationship between a woman and her baby to help promote exclusive breastfeeding and reduce the use of supplementary feeds. Early resolution of any breastfeeding challenges identified is key to success. In line with this goal to resolve breastfeeding challenges early in the relationship, a common theme identified within this review was that earlier frenotomy resulted in improved breastfeeding outcomes. The studies cited however often concluded that more research is needed to standardize optimal timing for frenotomy. What was clear from the studies reviewed was that the earlier the breastfeeding difficulties were resolved, the greater the chance that the woman would continue breastfeeding. The optimal timing of frenotomy should therefore be the focus of ongoing research.

Frenotomy is described by many performing clinicians as a pain and risk-free procedure; however, this was once thought to be the same of other infant procedures such as infant male circumcision. The impact on the child's psychosocial development has not been comprehensively researched and it needs to be, before a position that frenotomy is a painless and trauma free procedure is established. A further recommendation would therefore be for more in-depth research into the procedure of frenotomy itself focusing on the possibility that the infant experiences pain and distress associated with the procedure and whether any long-term sequela could result.

The final recommendation is for the development of standardized, evidence-informed information for parents on the diagnosis, incidence of and treatment options for tongue-tie to enable them to make their own decisions regarding the need for invasive treatment.

\section{CONCLUSION}

For a small percentage of infants experiencing significant breastfeeding problems ankyloglossia can be a contributing factor. Most of literature reviewed within this review suggests that frenotomy is a painless, simple procedure that on balance has more benefits than risk. However, the lack of studies with an experimental (frenotomy) and control (noninvasive management) group suggest that high-level evidence for or against frenotomy for symptomatic ankyloglossia cannot be established. Findings from this integrative review demonstrate that more randomized controlled studies need to be completed, comparing frenotomy with noninvasive, supportive interventions before parents and clinicians can know with confidence which is best practice.

\section{REFERENCES}

Amir, L., James, J., \& Donath, S. (2006). Reliability of the Hazelbaker Assessment Tool for Lingual Frenulum Function. International Breastfeeding Journal, 1, 3. http://dx.doi.org/10.1186/1746-4358-1-3

Berry, J., Griffiths, M., \& Westcott, C. (2012). A double-blind, randomized, controlled trial of tongue-tie division and its immediate effect on breastfeeding. Breastfeeding Medicine, 7(3), 189-193. http://dx.doi.org/10.1089/ bfm.2011.0030

Braccio, S., Chadderton, Z., Sherridan, A., \& Upadhyaya, M. (2016). Tongue-tie division. Is it worth it? A retrospective cohort study. British Journal of Midwifery, 24(5). http://dx.doi.org/10.12968/bjom.2016.24.5.317

Brookes, A., \& Bowley, D. M. (2014). Tongue tie: The evidence for frenotomy. Early Human Development, 90, 765-768. http://dx.doi.org/10.1016/j.earlhumdev.2014.08.021

Burrows, S., \& Lanlehin, R. (2015). Is frenotomy effective in improving breastfeeding in newborn babies with tonguetie? A literature review. British Journal of Midwifery, 23(11), 790-797. http://dx.doi.org/10.12968/bjom.2015.23.11.790

Buryk, M., Bloom, D., \& Shope, T. (2011). Efficacy of neonatal release of ankyloglossia: A randomized trial. Pediatrics, 128, 280-288. http://dx.doi.org/10.1542/peds.2011-0077

Dollberg, S., Marom, R., \& Botzer, E. (2014). Lingual frenotomy for breastfeeding difficulties: A prospective follow-up study. Breastfeeding Medicine, 9(6), 286-289. http://dx.doi.org/10.1089/bfm.2014.0010 
Edmunds, J. E., Fulbrook, P., \& Miles, S. (2013). Understanding the experiences of mothers who are breastfeeding an infant with tongue-tie: A phenomenological study. Journal of Human Lactation, 29(2), 190-195. http:// dx.doi.org/10.1177/0890334413479174

Edmunds, J. E., Miles, S., \& Fulbrook, P. (2011). Tongue-tie and breastfeeding: A review of the literature. Breastfeeding Review, 19(1), 19-26. Retrieved from http://search .informit.com.au/documentSummary; $\mathrm{dn}=9749153033$ 19900;res=IELHEA

Emond, A., Ingram, J., Johnson, D., Blair, P., Whitelaw, A., Copeland, M., \& Sutcliffe, A. (2014). Randomised controlled trial of early frenotomy in breastfed infants with mild-moderate tongue-tie. Archives of Disease in Childhood Fetal and Neonatal Edition, 99, 189-195. http://dx.doi.org/10.1136/archdischild-2013-305031

Francis, D. O., Krishnaswami, S., \& McPheeters, M. (2015). Treatment of ankyloglossia and breastfeeding outcomes: A systematic review. Pediatrics, 135(6), e1458-e1466. http://dx.doi.org/10.1542/peds.2015-0658

Ingram, J., Johnson, D., Copeland, M., Churchill, C., Taylor, H., \& Emond, A. (2015). The development of a tongue assessment tool to assist with tongue-tie identification. Archives of Disease in Childhood Fetal and Neonatal Edition, 100, F344-F348. http://dx.doi.org/10.1136/ archdischild-2014-307503

Kotlow, L. (2011). Diagnosis and treatment of ankyloglossia and tied maxillary fraenum in infants using Er:YAG and 1064 diode lasers. European Archives of Paediatric Dentistry, 12(2), 106-112. http://dx.doi.org/10.1007/ BF03262789

Martinelli, R. L., Marchesan, I. Q., Gusmão, R. J., Honório, H. M., \& Berretin-Felix, G. (2015). The effects of frenotomy on breastfeeding. Journal of Applied Oral Science, 23(2), 153-157. http://dx.doi.org/10.1590/ 1678-775720140339

Mettias, B., O’Brien, R., Abo Khatwa, M. M., Nasrallah, L., \& Doddi, M. (2013). Division of tongue tie as an outpatient procedure. Technique, efficacy and safety. International Journal of Pediatric Otorhinolaryngology, 77, 550-552. http://dx.doi.org/10.1016/j.ijporl.2013.01.003

O'Callahan, C., Macary, S., \& Clemente, S. (2013). The effects of office-based frenotomy for anterior and posterior ankyloglossia on breastfeeding. International Journal of Pediatric Otorhinolaryngology, 77, 827-823. http:// dx.doi.org/10.1016/j.ijporl.2013.02.022

Power, R. F., \& Murphy, J. F. (2015). Tongue-tie and frenotomy in infants with breastfeeding difficulties: Achieving a balance. Archives of Disease in Childhood, 100, 489-494. http://dx.doi.org/10.1136/archdischild-2014-306211

Riskin, A., Mansovsky, M., Coler-Botzer, T., Kugelman, A., Shaoul, R., Hemo, M., . . Bader, D. (2014). Tongue-tie and breastfeeding in newborns-mothers' perspective. Breastfeeding Medicine, 9(9), 430-437. http://dx.doi .org/10.1089/bfm.2014.0072

Rowan-Legg, A. (2015). Ankyloglossia and breastfeeding. Paediatrics \& Child Health, 20(4), 209-213.

Sethi, N., Smith, D., Kortequee, S., Ward, V. M., \& Clarke, S. (2013). Benefits of frenulotomy in infants with ankyloglossia. International Journal of Pediatric Otorhinolaryngology, 77, 762-765. http://dx.doi.org/10.1016/j.ijporl.2013.02.005

Steehler, M. W., Steehler, M. K., \& Harley, E. H. (2012). A retrospective review of frenotomy in neonates and infants with feeding difficulties. International Journal of Pediatric Otorhinolaryngology, 76, 1236-1240. http://dx.doi .org/10.1016/j.ijporl.2012.05.009

Todd, D. A. (2014). Tongue-tie in the newborn: What, when, who and how? Exploring tongue-tie division. Breastfeeding Review, 22(2), 7-10. Retrieved from http:// $\overline{\text { search.informit.com.au/documentSummary; } \mathrm{dn}=59868}$ 7183131831;res=IELHEA

Todd, D. A., \& Hogan, M. J. (2015). Tongue-tie in the newborn: Early diagnosis and division prevents poor breastfeeding outcomes. Breastfeeding Review, 23(1), 11-16.

Tsaousoglou, P., Topouzelis, N., Vouros, I., \& Sculean, A. (2016). Diagnosis and treatment of ankyloglossia: A narrative review and a report of three cases. Quintessence International, 47(6), 523-534. http://dx.doi .org/10.3290/j.qi.a36027

Whittemore, R., \& Knafl, K. (2005). The integrated review: Updated methodology. Journal of Advanced Nursing, 52(5), 546-553. http://dx.doi.org/10.1111/ j.1365-2648.2005.03621.x

Correspondence regarding this article should be directed to Ryndell Levkovich, RN, RM, Master of Primary Maternity Care, School of Nursing and Midwifery, Griffith University, Logan, Queensland, Australia. E-mail: Ryndell.levkovich@ uqconnect.edu.au

Ryndell Levkovich, RN, RM, Master of Primary Maternity Care. School of Nursing and Midwifery, Griffith University, Logan, Meadowbrook, Queensland, Australia.

Mary Sidebotham, PhD, RM, associate professor of Midwifery, director of Primary Maternity Care Programs, School of Nursing \& Midwifery, Griffith University, Logan, Queensland, Australia.

Karolyn Vaughan, PhD, RN, RM, C\&FHN, IBCLC, M Research, MIMH, School of Nursing and Midwifery, Griffith University, Logan, Queensland, Australia.

Elaine Dietsch, PhD, MN (WH), RM, School of Nursing and Midwifery, Griffith University, Logan, Meadowbrook, Queensland, Australia. 


\section{APPENDIX A Original Research Articles Included in Review}

\begin{tabular}{|c|c|c|c|}
\hline AUTHOR, DATE, TITLE & FOCUS/AIM & $\begin{array}{l}\text { METHODOLOGY } \\
\text { (SAMPLE, PARTICIPANTS) }\end{array}$ & SYNOPSIS OF MAIN FINDINGS \\
\hline $\begin{array}{l}\text { Berry et al. (2012) } \\
\text { A double-blind, ran- } \\
\text { domized, controlled } \\
\text { trial of tongue-tie } \\
\text { division and its } \\
\text { immediate effect on } \\
\text { breastfeeding }\end{array}$ & $\begin{array}{l}\text { Examine immediate } \\
\text { results of frenotomy } \\
\text { to determine if results } \\
\text { could be because of a } \\
\text { placebo effect rather } \\
\text { than frenotomy }\end{array}$ & $\begin{array}{l}\text { Randomized, double blind con- } \\
\text { trolled trial with } 30 \text { infants receiv- } \\
\text { ing a frenotomy and } 30 \text { infants not } \\
\text { receiving a frenotomy. All infants } \\
\text { were younger than } 4 \text { months old } \\
\text { with a diagnosed ankyloglossia } \\
\text { and breastfeeding problems. } \\
\text { Follow-up conducted 1-day } \\
\text { post- and } 3 \text { months' postproce- } \\
\text { dure (or nonprocedure). }\end{array}$ & $\begin{array}{l}\text { - Immediate improvement in breast- } \\
\text { feeding noted in } 78 \% \text { of infants who } \\
\text { underwent immediate frenotomy } \\
\text { compared with } 47 \% \text { of infants who } \\
\text { did not have the procedure. } \\
\text { - At the } 3 \text {-month follow-up, } 51 \% \\
\text { of infants (mean age } 4.5 \text { months) } \\
\text { who had a frenotomy continued to } \\
\text { breastfeed (compared with the na- } \\
\text { tional average of } 29 \% \text { at } 4 \text { months. } \\
\text { - Those in the frenotomy group saw } \\
\text { improvements in latch, pain, feeling } \\
\text { of feed, and maternal comfort. }\end{array}$ \\
\hline $\begin{array}{l}\text { Braccio et al. (2016) } \\
\text { Tongue-tie division. } \\
\text { Is it worth it? A } \\
\text { retrospective cohort } \\
\text { study }\end{array}$ & $\begin{array}{l}\text { Assessing the outcome of } \\
\text { frenotomy } \\
\text { Do breastfeeding prob- } \\
\text { lems improve after } \\
\text { frenotomy? } \\
\text { Are there complica- } \\
\text { tions associated with } \\
\text { frenotomy? } \\
\text { Are parents satisfied with } \\
\text { the service? }\end{array}$ & $\begin{array}{l}\text { Retrospective cohort survey con- } \\
\text { ducted over a 1-year period } \\
\text { A telephone survey where data } \\
\text { were entered on a standardized } \\
\text { questionnaire for each infant } \\
\text { Two-part survey } \\
\text { Part 1-feeding methods and } \\
\text { problems preprocedure, } 48 \text { hours } \\
\text { postprocedure and at time of } \\
\text { follow-up } \\
\text { Part } 2 \text {-quality of service of the } \\
\text { tongue-tie clinic }\end{array}$ & $\begin{array}{l}\text { - Increase in exclusive breastfeeding } \\
\text { rates from } 36.7 \% \text { preprocedure to } \\
53.8 \% \text { at } 48 \text { hours postprocedure } \\
\text { - Maternal feeding problems de- } \\
\text { creased from } 79.2 \% \text { preprocedure } \\
\text { to } 24.5 \% \text { at } 48 \text { hours post- and } \\
\text { down to } 2.7 \% \text { at follow-up } \\
\text { - Latch issues decreased from } 79.2 \% \\
\text { preprocedure to } 23.1 \% \text { at } 48 \text { hours } \\
\text { postprocedure to } 6.2 \% \text { at follow-up } \\
\text { - Statistically significant decreases in } \\
\text { frequent/long feeds and in infant } \\
\text { fussiness/restlessness at the breast } \\
\text { was also seen }\end{array}$ \\
\hline $\begin{array}{l}\text { Buryk et al. (2013) } \\
\text { Efficacy of neonatal } \\
\text { release of ankylo- } \\
\text { glossia: A random- } \\
\text { ized trial }\end{array}$ & $\begin{array}{l}\text { Does frenotomy improve } \\
\text { maternal nipple pain? } \\
\text { Does it improve ability to } \\
\text { breastfeed? } \\
\text { Does it impact on length } \\
\text { of breastfeeding }\end{array}$ & $\begin{array}{l}\text { Randomized single blinded, con- } \\
\text { trolled trial where infants with } \\
\text { breastfeeding difficulties and } \\
\text { significant ankyloglossia were } \\
\text { randomly assigned to either the } \\
\text { frenotomy ( } 30 \text { infants) or the } \\
\text { placebo procedure ( } 28 \text { infants). } \\
\text { Infants in the placebo group stayed } \\
\text { in the treatment room for the } \\
\text { same length of time but had no } \\
\text { procedure attended. Mothers from } \\
\text { both groups were instructed not } \\
\text { to look in the infant's mouth. This } \\
\text { study received Institutional Ethics } \\
\text { Committee approval. }\end{array}$ & $\begin{array}{l}\text { Mothers in both groups saw im- } \\
\text { mediate improvement in nipple } \\
\text { pain, but significantly higher rates } \\
\text { of improvement were noted in } \\
\text { frenotomy group. } \\
\text { - Breastfeeding assessment was con- } \\
\text { ducted using validated tools, and } \\
\text { improved breastfeeding scores were } \\
\text { noted only in the frenotomy group. } \\
\text { - Two-week follow-up control } \\
\text { group data not available because } \\
\text { all mothers (with one exception) } \\
\text { elected to have a frenotomy } \\
\text { performed on their infant. }\end{array}$ \\
\hline $\begin{array}{l}\text { Dollberg et al. (2014) } \\
\text { Lingual frenotomy } \\
\text { for breastfeeding } \\
\text { difficulties: A } \\
\text { prospective } \\
\text { follow-up study }\end{array}$ & $\begin{array}{l}\text { Explored long-term (up } \\
\text { to } 6 \text { months) impact of } \\
\text { frenotomy on breast- } \\
\text { feeding relationship }\end{array}$ & $\begin{array}{l}\text { Telephone survey with } 264 \text { mothers } \\
\text { whose infants had underwent } \\
\text { frenotomy for symptomatic } \\
\text { ankyloglossia, } 2 \text { weeks, } 3 \text { months, } \\
\text { and } 6 \text { months after the procedure }\end{array}$ & $\begin{array}{l}\text { - Positive long-term benefits of } \\
\text { frenotomy regarding length of } \\
\text { breastfeeding and rates of continued } \\
\text { breastfeeding. } \\
\text { - Seventy-five percent of mothers } \\
\text { experienced improvement in } \\
\text { breastfeeding postfrenotomy, but } 3 \% \\
\text { reported that the symptoms had wors- } \\
\text { ened } 2 \text { weeks after the frenotomy. } \\
\text { - At } 3 \text { and } 6 \text { months following the } \\
\text { procedure, } 68 \% \text { and } 56 \% \text { of moth- } \\
\text { ers continued to breastfeeding their } \\
\text { infants, respectively. } \\
\text { - Mothers identified the procedure as } \\
\text { nontraumatic. }\end{array}$ \\
\hline
\end{tabular}


APPENDIX A Original Research Articles Included in Review (Continued)

AUTHOR, DATE, TITLE
Edmunds et al. (2013)
Understanding the
experiences of
mothers who are
breastfeeding an
infant with tongue-
tie: A phenomeno-
logical study

tongue-tie
Emond et al. (2014)
Randomised con-
trolled trial of
breasty frenotomy in
with mild-moderate
tonfants

Martinelli et al. (2015) The effects of frenotomy on breastfeeding

\section{FOCUS/AIM}

To explore the mothers' perspective of breastfeeding an infant diagnosed with ankyloglossia

\section{METHODOLOGY}

(SAMPLE, PARTICIPANTS)

Qualitative (hermeneutic phenomenological) research study was conducted with 10 mothers whose infants had been diagnosed with symptomatic ankyloglossia.

\section{SYNOPSIS OF MAIN FINDINGS}

- Despite commitment to breastfeeding, women experienced disappointment and frustration with breastfeeding, However, following infant frenotomy, their breastfeeding experience significantly improved.

- Recommendation that screening for ankyloglossia should be a part of everyday infant examination

- Difference of clinical professional opinion noted between medical officers and lactation consultants/ midwives

- Medical officers did not usually recommend frenotomy or refer women to lactation consultants.

- Early identification and intervention recommended

To determine if early frenotomy improve breastfeeding difficulties when an infant has ankyloglossia, compared with standard (noninvasive) care and possible delayed frenotomy

To identify changes in breastfeeding patterns, postfrenotomy

- Early frenotomy did not result in ob-
Randomized controlled study of term infants, less than 2 weeks old with mild-moderate ankyloglossia and breastfeeding challenges. Randomization resulted in 55 infants having a frenotomy and a comparison group of 52 infants who received standard care but not a frenotomy. Mothers but not researchers were aware of the infant's frenotomy status.

Prospective longitudinal study: 14 infants in the experimental group (frenotomy) and 14 infants in the control group (no frenotomy)

All infants had been diagnosed with ankyloglossia and all breastfed with no other associated abnormalities or syndromes.
Mettias et al. (2013)

Division of tongue tie as an outpatient procedure. Technique, efficacy and safety.
Identify the outcome of frenotomy when performed under local anesthetic (average age of infants 4.1 weeks).
Questionnaire survey of mothers of 63 infants who had undergone frenotomy for diagnosed ankyloglossia
- The standard care group had a higher incidence of bottle feeding 5 days following either frenotomy or nonfrenotomy. jective breastfeeding improvements 5 days following the procedure

- Early frenotomy did improve maternal self-efficacy. The majority of the comparison arm opted for frenotomy immediately after the data were collected.

- Increase in the number of sucks per minute postfrenotomy.

- Decrease in the pause length between suck clusters postfrenotomy.

- Decrease in mothers breastfeeding complaints when the infant had frenotomy.

- Control infants had no change in breastfeeding pattern.

- At 30 and 75 days' postfrenotomy, breastfeeding difficulties had reduced and suck/swallow/breathing coordination had improved, whereas those who had not had a frenotomy remained unchanged.

- Following frenotomy, all maternal symptoms experienced by the mothers had improved.

- Postfrenotomy, all preprocedure feeding problems resolved in $98.4 \%$ of breastfeeding mother-infant dyads.

- Parents found procedure to be quick and minimally distressful.

- Early diagnosis and referral optimal for good outcomes

- Improves breastfeeding outcomes and infant weight gain 
APPENDIX A Original Research Articles Included in Review (Continued)

\begin{tabular}{|c|c|c|c|}
\hline AUTHOR, DATE, TITLE & FOCUS/AIM & $\begin{array}{l}\text { METHODOLOGY } \\
\text { (SAMPLE, PARTICIPANTS) }\end{array}$ & SYNOPSIS OF MAIN FINDINGS \\
\hline $\begin{array}{l}\text { O'Callahan et al. } \\
\text { (2013) } \\
\text { The effects of office- } \\
\text { based frenotomy for } \\
\text { anterior and poste- } \\
\text { rior ankyloglossia } \\
\text { on breastfeeding }\end{array}$ & $\begin{array}{l}\text { To determine if fre- } \\
\text { notomy reverses } \\
\text { breastfeeding difficul- } \\
\text { ties in babies with } \\
\text { ankyloglossia } \\
\text { To examine the char- } \\
\text { acteristics of both } \\
\text { anterior and posterior } \\
\text { ankyloglossia }\end{array}$ & $\begin{array}{l}\text { Web-based questionnaire completed } \\
\text { by } 299 \text { mothers prior to and post- } \\
\text { frenotomy } \\
\text { Infants had been referred by pediatri- } \\
\text { cian for frenotomy because of } \\
\text { breastfeeding difficulties feeding } \\
\text { and/or poor weight gain. }\end{array}$ & $\begin{array}{l}\text { - Frenotomy procedure can improve } \\
\text { breastfeeding difficulties when } \\
\text { related to ankyloglossia. } \\
\text { - Recommendation made that screening } \\
\text { for ankyloglossia should be routinely } \\
\text { conducted by health professionals. } \\
\text { - Frenotomy should be routinely } \\
\text { offered to mothers following symp- } \\
\text { tomatic ankyloglossia diagnosis. }\end{array}$ \\
\hline $\begin{array}{l}\text { Riskin et al. (2014) } \\
\text { Tongue-tie and } \\
\text { breastfeeding in } \\
\text { newborns-mothers' } \\
\text { perspective }\end{array}$ & $\begin{array}{l}\text { Explore mothers' experi- } \\
\text { ences of a tongue-tie } \\
\text { infant and evalua- } \\
\text { tion of the assistance } \\
\text { provided to them. }\end{array}$ & $\begin{array}{l}\text { Retrospective, single center observa- } \\
\text { tional study using a structured sur- } \\
\text { vey instrument with } 183 \text { mothers } \\
\text { whose infants had been diagnosed } \\
\text { with ankyloglossia and a control } \\
\text { group of } 314 \text { mothers whose in- } \\
\text { fants did not have ankyloglossia. }\end{array}$ & $\begin{array}{l}\text { - Similar breastfeeding rates of breast- } \\
\text { feeding problems in the first month } \\
\text { were noted in both the infants with } \\
\text { ankyloglossia group and the control } \\
\text { group ( } 59 \% \text { and } 52 \% \text {, respectively). } \\
\text { - Similar breastfeeding rates at } 6 \text { months } \\
\text { in both groups. However, mothers } \\
\text { whose infants had ankyloglossia report- } \\
\text { ed significantly more problems with } \\
\text { latching, prolonged breastfeeding time, } \\
\text { and infant exhaustion during feeding } \\
\text { but no increased pain or sore nipples. } \\
\text { - Mothers of infants with ankyloglos- } \\
\text { sia were more likely than mothers } \\
\text { in the control group to } \\
\text { - Express milk and/or supplement } \\
\text { infant } \\
\text { - Require consultation after discharge } \\
\text { - Report that they were assisted by } \\
\text { lactation consultants } \\
\text { - Be dissatisfied with frenotomy if } \\
\text { done in the absence of breast- } \\
\text { feeding problems }\end{array}$ \\
\hline $\begin{array}{l}\text { Sethi et al. (2013) } \\
\text { Benefits of frenuloto- } \\
\text { my in infants with } \\
\text { ankyloglossia }\end{array}$ & $\begin{array}{l}\text { Evaluation of indica- } \\
\text { tions and outcomes } \\
\text { of frenotomy }\end{array}$ & $\begin{array}{l}\text { Telephone questionnaire completed } \\
\text { by } 52 \text { mothers who had experi- } \\
\text { enced breastfeeding difficulties } \\
\text { prior to frenotomy. The telephone } \\
\text { questionnaire was attended post- } \\
\text { procedure. }\end{array}$ & $\begin{array}{l}\text { - Most mothers }(77 \%) \text { reported im- } \\
\text { provement in breastfeeding relation- } \\
\text { ship immediately or within } 2 \text { weeks } \\
\text { of procedure. } \\
\text { - No mothers reported increased } \\
\text { breastfeeding difficulties. } \\
\text { - Some ( } 23 \%) \text { reported no difference } \\
\text { with breastfeeding. } \\
\text { - No impact seen on duration of } \\
\text { breastfeeding relationship }\end{array}$ \\
\hline $\begin{array}{l}\text { Steehler et al. (2012) } \\
\text { A retrospective review } \\
\text { of frenotomy in } \\
\text { neonates and } \\
\text { infants with feeding } \\
\text { difficulties }\end{array}$ & $\begin{array}{l}\text { To determine if timing } \\
\text { of frenotomy impacts } \\
\text { on the breastfeeding } \\
\text { outcome } \\
\text { Measure of maternal } \\
\text { breastfeeding benefits } \\
\text { postfrenotomy }\end{array}$ & $\begin{array}{l}\text { Review of } 367 \text { medical records of in- } \\
\text { fants with suspected symptomatic } \\
\text { ankyloglossia, } 302 \text { of whom un- } \\
\text { derwent frenotomy. Followed by } \\
\text { telephone survey with } 91 \text { mothers } \\
\text { whose infants had frenotomy. }\end{array}$ & $\begin{array}{l}\text { - Frenotomy effectively improved } \\
\text { breastfeeding for infants with symp- } \\
\text { tomatic ankyloglossia. } \\
\text { - Greater benefit when frenotomy } \\
\text { performed in first week of life, } \\
\text { rather than later. } \\
\text { - Frenotomy still offered benefit if } \\
\text { performed later. }\end{array}$ \\
\hline $\begin{array}{l}\text { Todd and Hogan } \\
\text { (2015) } \\
\text { Tongue-tie in the } \\
\text { newborn: Early } \\
\text { diagnosis and } \\
\text { division prevents } \\
\text { poor breastfeeding } \\
\text { outcomes }\end{array}$ & $\begin{array}{l}\text { Identify the incidence } \\
\text { of tongue-tie and } \\
\text { breastfeeding difficul- } \\
\text { ties in infants with } \\
\text { ankyloglossia. } \\
\text { To determine the most } \\
\text { effective timing of fre- } \\
\text { notomy in terms of im- } \\
\text { pact on breastfeeding }\end{array}$ & $\begin{array}{l}\text { Prospective study of } 2,471 \text { infants } \\
\text { who had frenotomy at an average } \\
\text { age of } 6.5 \text { days ( } \pm 4.5 \text { days) in } \\
2008 \text { with } 2,891 \text { infants who had } \\
\text { a frenotomy at an average age of } \\
9.7 \text { days ( } \pm 6.2 \text { days) in } 2011 \text {. }\end{array}$ & $\begin{array}{l}\text { - The older the infant at the time of } \\
\text { frenotomy, the greater the number } \\
\text { of mothers who were unable to } \\
\text { breastfeed. } \\
\text { - Increased rates of nipple damage, } \\
\text { mastitis, engorgement, decreased milk } \\
\text { supply, and difficulty with babies tran- } \\
\text { sitioning back to the breast if frenoto- } \\
\text { my was delayed until after } 7 \text { days. }\end{array}$ \\
\hline
\end{tabular}




\section{APPENDIX B Review Articles Included in This Review}

\begin{tabular}{|c|c|c|c|}
\hline ARTICLE & FOCUS/AIM & $\begin{array}{l}\text { METHODOLOGY (SAMPLE, } \\
\text { PARTICIPANTS) }\end{array}$ & SYNOPSIS OF MAIN FINDINGS \\
\hline $\begin{array}{l}\text { Brookes and Bowley } \\
\text { (2014) } \\
\text { Tongue tie: The } \\
\text { evidence for } \\
\text { frenotomy }\end{array}$ & $\begin{array}{l}\text { To outline the role of } \\
\text { frenotomy in clinical } \\
\text { practice }\end{array}$ & Unspecified literature review & $\begin{array}{l}\text { - Evidence that with breast- } \\
\text { feeding problems, frenotomy } \\
\text { should be offered. } \\
\text { - No conclusive evidence that } \\
\text { prophylactic frenotomy helps } \\
\text { possible future issues such as } \\
\text { speech development. } \\
\text { - No mortality and low mor- } \\
\text { bidity, so no reason not to } \\
\text { be offered to women whose } \\
\text { infant's ankyloglossia is causing } \\
\text { breastfeeding problems. } \\
\text { - Frenotomy should be offered } \\
\text { along with holistic breastfeeding } \\
\text { support as a multidimensional } \\
\text { approach. }\end{array}$ \\
\hline $\begin{array}{l}\text { Burrows and Lanlehin } \\
\text { (2015) } \\
\text { Is frenotomy effective } \\
\text { in improving } \\
\text { breastfeeding in } \\
\text { newborn babies } \\
\text { with tongue-tie? } \\
\text { A literature review }\end{array}$ & $\begin{array}{l}\text { To determine if breast- } \\
\text { feeding is more } \\
\text { successful in new- } \\
\text { borns with ankyloglos- } \\
\text { sia who have had a } \\
\text { frenotomy }\end{array}$ & $\begin{array}{l}\text { Systematic literature review } \\
\text { of nine research articles } \\
\text { retrieved from OVID online } \\
\text { and EBSCOhost } \\
\text { Two critical appraisal tools } \\
\text { used: Critical Skills Appraisal } \\
\text { Program and British Medical } \\
\text { Journal appraisal tool } \\
\text { Focused on mother's } \\
\text { experiences }\end{array}$ & $\begin{array}{l}\text { - Frenotomy effective for } \\
\text { reducing nipple pain and } \\
\text { improving infants latch } \\
\text { - Frenotomy should not be } \\
\text { used as a stand-alone inter- } \\
\text { vention but alongside other } \\
\text { breastfeeding supports. }\end{array}$ \\
\hline $\begin{array}{l}\text { Edmunds et al. (2011) } \\
\text { Tongue-tie and } \\
\text { breastfeeding: } \\
\text { A review of the } \\
\text { literature }\end{array}$ & $\begin{array}{l}\text { To determine if interven- } \\
\text { tion can reduce the } \\
\text { impact of ankyloglos- } \\
\text { sia on breastfeeding } \\
\text { outcomes and if early } \\
\text { intervention increases } \\
\text { the duration of } \\
\text { breastfeeding } \\
\text { Examination of medical } \\
\text { opinion regarding } \\
\text { management and } \\
\text { treatment }\end{array}$ & Unspecified literature review & $\begin{array}{l}\text { - Ankyloglossia negatively affects } \\
\text { breastfeeding. } \\
\text { - If the ankyloglossia does not af- } \\
\text { fect breastfeeding, no treatment } \\
\text { is recommended } \\
\text { - If breastfeeding is affected, } \\
\text { frenotomy is recommended } \\
\text { and offers significant benefit. } \\
\text { - Frenotomy is safe, effective, } \\
\text { and simple. } \\
\text { - There is no universal consen- } \\
\text { sus in the medical profession } \\
\text { on whether frenotomy should } \\
\text { be used to treat ankyloglossia } \\
\text { when there are breastfeeding } \\
\text { problems. } \\
\text { - More education is required for } \\
\text { all health professionals regard- } \\
\text { ing the safety and simplicity of } \\
\text { frenotomy. }\end{array}$ \\
\hline
\end{tabular}


APPENDIX B Review Articles Included in This Review (Continued)

\begin{tabular}{|c|c|c|c|}
\hline ARTICLE & FOCUS/AIM & $\begin{array}{l}\text { METHODOLOGY (SAMPLE, } \\
\text { PARTICIPANTS) }\end{array}$ & SYNOPSIS OF MAIN FINDINGS \\
\hline $\begin{array}{l}\text { Francis et al. (2015) } \\
\text { Treatment of } \\
\text { ankyloglossia } \\
\text { and breastfeeding } \\
\text { outcomes: A sys- } \\
\text { tematic review }\end{array}$ & $\begin{array}{l}\text { To review both surgical } \\
\text { and nonsurgical } \\
\text { treatments for infants } \\
\text { with ankyloglossia }\end{array}$ & $\begin{array}{l}\text { Systematic literature review } \\
\text { of } 29 \text { studies reporting } \\
\text { breastfeeding effective- } \\
\text { ness outcomes following } \\
\text { frenotomy for symptomatic } \\
\text { ankyloglossia }\end{array}$ & $\begin{array}{l}\text { - Low level to insufficient } \\
\text { evidence that frenotomy is } \\
\text { associated with improved } \\
\text { breastfeeding outcomes } \\
\text { (mother-reported improvements } \\
\text { in breastfeeding and nipple } \\
\text { pain) } \\
\text { - Studies reviewed were small, } \\
\text { short-term with inconsistent } \\
\text { methodologies } \\
\text { - Lack of research on nonsurgical } \\
\text { interventions and their impact } \\
\text { on breastfeeding outcomes }\end{array}$ \\
\hline $\begin{array}{l}\text { Power and Murphy } \\
\text { (2015) } \\
\text { Tongue-tie and fre- } \\
\text { notomy in infants } \\
\text { with breastfeed- } \\
\text { ing difficulties: } \\
\text { Achieving a } \\
\text { balance }\end{array}$ & $\begin{array}{l}\text { Examination of how the } \\
\text { argument for ankylo- } \\
\text { glossia treatment has } \\
\text { evolved } \\
\text { Exploration of how to } \\
\text { best inform mothers } \\
\text { when their infants } \\
\text { have ankyloglossia- } \\
\text { related breastfeeding } \\
\text { problems }\end{array}$ & Unspecified literature review & $\begin{array}{l}\text { - Fifty percent of babies with } \\
\text { ankyloglossia do not need } \\
\text { intervention. } \\
\text { - High-level assessment skills } \\
\text { needed } \\
\text { - Trained practitioners only to } \\
\text { perform frenotomy } \\
\text { - Frenotomy does appear to } \\
\text { improve breastfeeding in } \\
\text { infants with ankyloglossia. } \\
\text { - Unable to quantify the placebo } \\
\text { effect } \\
\text { - Complications are rare. }\end{array}$ \\
\hline $\begin{array}{l}\text { Todd (2014) } \\
\text { Tongue-tie in the } \\
\text { newborn: What, } \\
\text { when, who, and } \\
\text { how? Exploring } \\
\text { tongue-tie division }\end{array}$ & $\begin{array}{l}\text { To identify how the type } \\
\text { of ankyloglossia af- } \\
\text { fects breastfeeding } \\
\text { To identify which types } \\
\text { of ankyloglossia } \\
\text { should be divided and } \\
\text { which should not be } \\
\text { treated } \\
\text { To determine the health } \\
\text { professional groups } \\
\text { who should attend } \\
\text { frenotomy, how it is } \\
\text { best attended, and the } \\
\text { optimal timing for the } \\
\text { procedure }\end{array}$ & Unspecified literature review & $\begin{array}{l}\text { - Wide range of tongue-tie types } \\
\text { - Appearance of tongue-tie varies } \\
\text { - Type does not indicate how the } \\
\text { infant will feed. } \\
\text { - Frenotomy should be attended } \\
\text { in first few days of life. } \\
\text { - All mothers should have the } \\
\text { option of frenotomy for their } \\
\text { infant if the ankyloglossia is } \\
\text { affecting breastfeeding ability/ } \\
\text { comfort. } \\
\text { - Infant should have had vitamin } \\
\text { K prior to frenotomy to reduce } \\
\text { the risk of bleeding. } \\
\text { - Delay of treatment will cascade } \\
\text { feeding problems resulting in } \\
\text { earlier cessation of feeding. }\end{array}$ \\
\hline
\end{tabular}

